\title{
Concentrated solar power: technology, economy analysis, and policy implications in China
}

\author{
Yan $\mathrm{Xu}^{1} \cdot$ Jiamei Pei ${ }^{1} \cdot$ Jiahai Yuan $^{2} \cdot$ Guohao Zhao ${ }^{1}$ \\ Received: 28 February 2021 / Accepted: 29 July 2021 / Published online: 5 August 2021 \\ (C) The Author(s), under exclusive licence to Springer-Verlag GmbH Germany, part of Springer Nature 2021
}

\begin{abstract}
Renewable energy plays a significant role in achieving energy savings and emission reduction. As a sustainable and environmental friendly renewable energy power technology, concentrated solar power (CSP) integrates power generation and energy storage to ensure the smooth operation of the power system. However, the cost of CSP is an obstacle hampering the commercialization of this emerging industry, so the paper studies the technical characteristics, economic analysis, and policy implications of CSP. This paper sorts out the relevant policies of CSP and uses the levelized cost of electricity ( $L C O E)$ model by considering financial parameters, investment parameters, operation and maintenance parameters, tax parameters, capacity parameters, etc., to analyze the economics of CSP. The model parameters are set by the actual situation of CSP projects. The economic evaluation of different technology types of parabolic trough (PT), solar tower (ST), secondary reflection ST, and linear Fresnel reflector (LFR) is carried out. The $L C O E$ of PT project is $1.11 \mathrm{RMB} / \mathrm{kWh}(0.17 \mathrm{US} \$ / \mathrm{kWh})$, the ST project is $0.93 \mathrm{RMB} / \mathrm{kWh}(0.14 \mathrm{US} \$ / \mathrm{kWh})$, the secondary reflection ST project is $0.97 \mathrm{RMB} / \mathrm{kWh}(0.15 \mathrm{US} \$ / \mathrm{kWh})$, and the LFR project is $0.92 \mathrm{RMB} / \mathrm{kWh}(0.14 \mathrm{US}$ $\$ / \mathrm{kWh}$ ). The results show that the grid parity era of CSP in China is within reach, and ST is the most potential technology type. Based on the results of economic analysis and the problems faced by CSP in China, this paper puts forward policy implications by preferential loans, tax incentives, and R\&D fund support to promote the development of CSP.
\end{abstract}

Keywords Concentrated solar power $\cdot$ Economy $\cdot L C O E$ model $\cdot$ On-grid price $\cdot$ Grid parity $\cdot$ China

\section{Introduction}

Xi Jinping, the president of China, has elucidated the overarching objective for tackling climate change, that is, China will adopt more powerful policies and measures to achieve carbon peak by 2030 and carbon neutrality by 2060 (Sun 2020). In making plans to reduce $\mathrm{CO}_{2}$ emissions, governments of different nations have primarily put stress on the power sector, among which the renewable energy power has developed very quickly. As a renewable energy, solar power

Responsible Editor: Philippe Garrigues

Yan Xu

xwwyfy@sina.com

1 School of Management Science and Engineering, Shanxi University of Finance and Economics, No 696, Wucheng Road,

Taiyuan 030006, Shanxi, China

2 School of Economics and Management, North China Electric Power University, Beijing 102206, China is exhaustible. In terms of environmental protection and energy conservation, solar power technology has inherent advantages (Wang et al. 2016).

China has become one of the largest energy consumers and energy-related $\mathrm{CO}_{2}$ emitters in the world and has made great contributions to $\mathrm{CO}_{2}$ emission reduction (Song et al. 2019). Therefore, the influencing factor of $\mathrm{CO}_{2}$ emissions has becoming a hot topic for researchers. From provincial region perspectives, Zhang et al. (2019) conducted a decomposition analysis of the drivers governing $\mathrm{CO}_{2}$ emissions by studying the details of China's 41 industry subsectors over the period 2000-2016. The initial declines in energy consumption at China's provincial level and its drivers were explored by $\mathrm{Ou}$ et al. (2019). Song et al. (2020) used the Tapio- $Z$ decoupling model to evaluate the decoupling status of China's $\mathrm{CO}_{2}$ emissions at provincial level and its dynamic trend. Many scholars have also studied the relationship between carbon dioxide emissions and economic development. Fujii et al. (2018) explored the environmental Kuznets curve hypothesis between 276 global metropolitan's $\mathrm{CO}_{2}$ emissions and economic growth and found that there existed an inverted U-shape 
relationship between $\mathrm{CO}_{2}$ emissions and GDP. In the literature of Song and Zhang (2019), the decoupling state of $\mathrm{CO}_{2}$ emissions in most countries from economic development (GDP) is studied. Ning et al. (2020) proposed that high-quality economic development may generate good effects on energy conservation and emission reduction. In addition, $\mathrm{CO}_{2}$ emissions and policies are inseparable. Wang (2018b) further pointed out that regional differences can result in different effects of environmental regulation, and the increase of the intensity of environmental regulation will promote carbon emissions in some regions. A diffusion model of energy technology based on endogenous technology learning under bounded rationality is developed to explore the possible impacts of different carbon tax conditions on the diffusion of energy technologies in China (Ding et al. 2019). Lu and Luo (2020) used double difference method to analyze the impact of carbon trading policy on $\mathrm{CO}_{2}$ emissions and $\mathrm{CO}_{2}$ emission intensity and tested the applicability of double difference method to evaluate carbon trading policy. Zhang et al. (2021) indicated that the central government should strengthen targeted supervision and adaptive incentives for local governments to implement environmental regulation so that joint emission reduction can be realized. However, the fossil fuel burning is the main source of $\mathrm{CO}_{2}$ emissions. Thus, exploitation and using of clean and renewable energy are of great importance for China.

At present, solar power generation technology can be divided into solar photovoltaic power $(P V)$ and concentrated solar power (CSP) (Chen and Fan 2012). Solar $P V$ power generation utilizes photoelectric effect to directly convert solar energy into electricity, which is a direct photoelectric conversion mode. CSP is light-heat-electric conversion mode which converts the absorbed heat energy into steam through a solar collector and then drives a steam turbine to generate electricity. Solar $P V$ has been developed for a long time, and the technology is relatively mature, but there are still some technical problems that are difficult to solve. Photovoltaic panels, which are necessary for solar $P V$, will pollute the environment in the production process, and photovoltaic modules will also cause serious harm to the environment in the recycling process. In addition, due to the intermittent nature of light-receiving resources, solar $P V$ is unstable, and there is a serious abandonment of light (Zhang 2018). Although the use of storage devices can enable the smooth operation of solar $P V$, the high price of batteries increases the electricity cost, so it is still not widely used at present (Pan et al. 2017). In contrast, CSP uses physical means for energy conversion, which has minimal harm to the environment. And due to its own technical characteristics, CSP has a heat storage device and an auxiliary power generation system, which integrates power generation and energy storage. The output is stable and reliable, and the adjustment performance is excellent which can ensure the smooth operation of the power system and has better grid friendliness.
Promoting the development of CSP will increase the proportion of renewable energy that connects to the grid and will improve the national contribution to $\mathrm{CO}_{2}$ emission reduction which aids to speed up the process of carbon peak by 2030 and helps to achieve carbon neutrality by 2060 . CSP plays a positive role in strengthening the domestic determination of low-carbon transformation and global climate governance. But at the same time, CSP also faces huge challenges, mainly due to the high cost compared with other renewable energy such as solar photovoltaic. Therefore, attention should be paid to CSP research and development.

As an emerging clean energy technology, CSP technology is clean and pollution-free in the whole power generation process, which brings significant environmental benefits. CSP has rapidly promoted around the world. It is estimated that parabolic trough and solar tower plants emit $26 \mathrm{~g} / \mathrm{kWh}$ and $38 \mathrm{~g} /$ kWh CO$~_{2}$ (Burkhardt et al. 2012). In 2015, National Energy Administration (NEA) issued "The Notice on the Organization of CSP Demonstration Projects Construction," which planned to build $1 \mathrm{GW}$ CSP demonstration projects to promote the development of China's CSP industry (NEA 2015). In addition to technology maturity, the main factors affecting the development of CSP include the initial investment cost, operation, and planning of CSP (Du et al. 2016). Like all emerging industries, the initial investment cost of CSP is high. Researches show that project scale (Sharma et al. 2016; Wang 2009; Li et al. 2015), heat storage device (Balghouthi et al. 2016; Cirocco et al. 2016; Parrado et al. 2016), and development and demonstration investment cost (Bosetti et al. 2012) all affect the initial investment cost. The difficulty and key problem in the study of CSP is its operation, which involves the integration and coordination of multiple systems such as solar heat collection, heat transfer and heat storage, and power generation (Du et al. 2016). Scholars from other countries established the static energy flow model of Fresnel CSP and the thermodynamic and dynamic equations of each link of the solar tower system and used actual data to simulate the operation of the CSP, calculating its operating efficiency (Flueckiger et al. 2014; Li 2012). In addition, in order to maximize CPS benefits, a large number of studies in recent years have combined the model of CSP with the power market model to optimize the operation strategy (Dominguez et al. 2012; Petrollese et al. 2017). The study of CSP in western countries is ahead of that in China, so there are more academic studies on the optimization planning of CSP in western countries. Now Europe and the USA have developed some mature CSP planning software, and the System Advisor Model (SAM) developed by NERL Lab in the USA is widely used. Du et al. (2018) Grid Optimization Planning Tool which is developed by the Electrical Engineering Department of Tsinghua University analyzed the energy benefits of Qinghai Power Grid and Gansu Power Grid after accessing CSP and the flexibility benefits of reducing wind and light abandonment. 
Many current studies have assessed the economic viability of different types of CSP technologies at home and abroad. In literature of Suzan (2021), SAM was used to model and simulate the Egyptian 50MW solar dish, and the estimated LCOE was 13.38 cents/kWh. Sharma et al. (2016) compared and analyzed the economy of PT and LFR technology types in India. Shah et al. (2014) analyzed the economics of four different CSP technologies in Australia. The result showed that the solar tower is more economical. Janjai et al. (2011) used the Transient System Simulation Program (TRNSYS) software and the solar thermal electric component (STEC) subroutine to study the economy of three technology types (parabolic trough, solar tower, and solar dish) in Thailand. The results showed that the parabolic trough type is more economical, with an $L C O E$ of $0.30 \mathrm{US} \$ / \mathrm{kWh}$. Zhu et al. (2015) firstly analyzed the economy of three CSP technologies (parabolic trough, solar tower, and solar dish) in China in 2015, and the results showed that at the current stage, the $L C O E$ value of the three technology types was between 1.2 and $2.7 \mathrm{RMB} / \mathrm{kWh}$, and solar tower was the most economical one. However, this study still has some limitations. In 2015, China's CSP projects were in the demonstration period, and CSP projects were all new projects with small scale and immature technology, which resulted in high cost to some extent. Some key data were obtained through system simulation and expert interview, so it is difficult to obtain complete data. At that time, there was no specific policy on CSP, and the study was based on China's current renewable energy and solar photovoltaic policies. As the CSP technology is becoming mature and the national policies are becoming more and more perfect, there are still few literatures to evaluate the economic performance of different technology types of CSP in China. Therefore, this paper adopts the $L C O E$ method to analyze the economic performance of four CSP technologies.

The contributions of this paper are as follows: (1) it comprehensively sorted out the existing CSP projects and the development policies of CSP industry. (2) This paper uses $L C O E$ model to analyze and compare different technology types of PT, ST, secondary reflection ST, and LFR from economic perspective. (3) The policy implications are put forward from preferential loans, tax incentives, and R\&D fund support to promote the rapid development of the CSP industry.

The remainder of the paper will be organized as follows. The "Current status of CSP in China" section presents the cumulative installed capacity, operating projects and projects under construction, technological innovation, and policy review. The "Methodology" section discusses the LCOE model and related variables and factors. The project characteristics are presented in the "Parameterization and assumptions" section. The "Results" section shows the calculation of $\angle C O E$ of different CSP projects. In the "Policy implications" section, preferential loans policies, tax incentives, and R\&D fund support are discussed. The "Conclusion" section summarizes the main points of this paper.

\section{Current status of CSP in China}

As one of the important renewable energy, solar energy has taken up significant position in the global energy system in recent years. CSP has entered the practical stage in some developed countries, China's research on CSP started late, and the level of commercialization is still low. However, some key technologies have been mastered. Market is promising with rapid development and broad prospects (Wang et al. 2014).

\section{Cumulative installed capacity}

In 2019, the global installed capacity of CSP continued to grow, but at a small rate. The global installed capacity of CSP has increased by $381.6 \mathrm{MW}$, and the total installed capacity has increased to approximately $6451 \mathrm{MW}$ on the basis of $6069 \mathrm{MW}$ in 2018, an increase of 6.29\%. Among them, CSP in China has newly installed 200MW, accounting for $52.41 \%$ of the world's total new installed capacity. China accounts for more than half of the newly installed capacity, and its activity and influence in the global CSP industry continue to increase (CSPPLAZA 2020a).

As shown in Figure 1, by the end of 2019, the total installed capacity of nonrenewable energy power generation in China was $1214.62 \mathrm{GW}$, accounting for $60.5 \%$ of the total installed capacity; the total installed capacity of renewable energy power generation was $794.8 \mathrm{GW}$, an increase of $8.6 \%$ year-on-year, accounting for $39.5 \%$ of the total installed capacity and $57.4 \%$ of the new installed capacity, and it was becoming an important component of energy transition. Among them, the installed capacity of hydropower was $326.11 \mathrm{GW}$, accounting for the largest proportion. The installed capacity of biomass power was $23.69 \mathrm{GW}$, accounting for the least. The installed capacity of solar power in China had grown steadily. The newly installed capacity of solar power was $30.3 \mathrm{GW}$ (including an increase of $200 \mathrm{MW}$ for CSP), and the cumulative installed capacity had reached 204.74GW (including 440 MW of CSP). Hydropower, wind power, solar power, biomass power generation, and renewable energy installed capacity ranked first in the world (Xin 2020).

\section{Operating projects and projects under construction}

The CSP technology in China has a wide range of technical routes, basically covering international mainstream technical routes such as parabolic trough (PT), solar tower (ST), solar dish (SD), and linear Fresnel reflector (LFR). Apart from those mentioned above, Fresnel-like, secondary reflection ST, etc., which are the first to be applied internationally, are included as well. It marks that China's CSP technology has reached the international leading level to a certain extent. Table 1 shows some large-scale CSP projects that have been put into operation and will be put into operation in China. 
Fig. 1 Cumulative installed capacity and proportion of various power sources in 2019

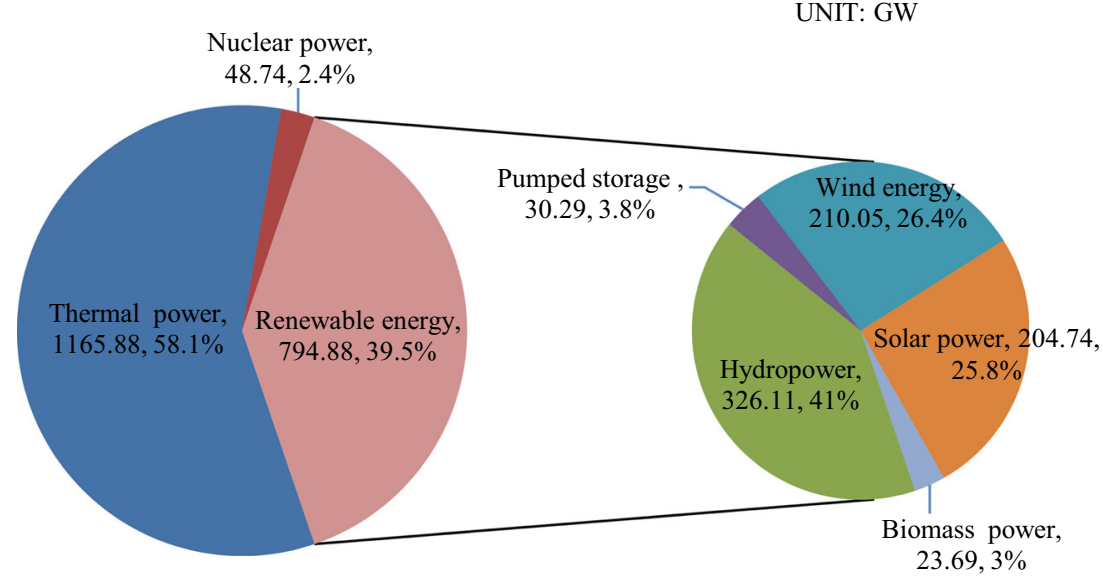

In the 1970s, China started the research of CSP, but before 2015, it was still in the development stage (Niu and Li 2020). In 2012, the key project of the National 863 Program "CSP Technology and System Demonstration"-Yanqing Badaling 1 MW ST Project successfully generated power after 6 years, which is a milestone in the history of CSP industry in China (CSPPLAZA 2017a). In 2013, Qinghai Supcon Delingha's 10 MW ST was connected to the power grid, filling the gap in the grid-connected power of CSP in China, and CSP technology has taken a solid step toward commercial operation (Polaris 2020b). In 2016, NEA officially issued "The Notice of the National Energy Administration on the Construction of CSP Demonstration Projects," which announced the first batch of 20 CSP demonstration projects, including 7 PT projects, 9 ST projects, and 4 Fresnel projects. Subsequently, the first batch of large-scale commercial CSP projects entered the substantive construction stage (NEA 2016c). In 2018, China's first large-scale commercialized CSP demonstration project (CGN Delingha 50MW CSP demonstration project) was officially put into operation, and it marked that China has been the eighth country in the world to master large-scale CSP technology (SASAC 2018). At the end of 2019, Qinghai Gonghe $50 \mathrm{MW}$ Molten Salt ST project (Power Construction Corporation of China), Haixi Golmud 50MW Molten Salt ST project (Luneng Group Co., LTD.), Hami 50MW Molten Salt ST project (China Power Engineering Consulting (Group) Corporation), and Lanzhou Dacheng Dunhuang 50MW Molten Salt LFR project were successfully connected to the grid (CSPPLAZA 2019a; CSPPLAZA 2019b; CSPFocus 2019; Gansu 2020). By 2020, 7 of the first 20 demonstration projects $(450 \mathrm{MW})$ have been constructed and put into operation (NEA 2020). In addition, the Multi-energy Complementary Integration and Optimization National Demonstration Project in Haixi Prefecture was officially connected to the power grid in September 2020. Since then, China has become the first country in the world with a multi-functional complementary project integrating wind-solar-heat-storage-peak shaving-load. Relying on the
50MW CSP project and energy storage battery, the project completely got rid of thermal power peak shaving and realized $100 \%$ of new energy delivery, which is a milestone in the history of China's new energy development (CSPPLAZA 2020c). In addition, New Energy CSP and Energy Storage Base Project (Inner Mongolia), Multi-energy Complementary Project (Yumen), and Golmud Kunlun Solar City Project which will be led by CSP and other industries have all been planned and promoted (CSPPLAZA 2020b).

\section{Technological innovation}

CSP technology can be categorized into PT, ST, SD, and LFR in terms of different concentration mode and concentration ratio. Among them, PT and LFR are line concentration, and ST and SD are point concentration (Sun and Bai 2017). The PT system reflects the solar energy into the heat-absorbing tube through trough-type parabolic mirrors. The ST system uses a group of heliostats that independently track the sun to concentrate sunlight on the receiver on the top of the tower. The LFR system uses one set of flat mirrors to replace the parabolic curved mirrors in the trough system for focusing. The SD system uses a rotatable parabolic mirror to focus the sunlight on the solar receiver at the focal point or installs solar stirling directly at the focal point device to absorb solar energy, heat the working fluid, and the heated working fluid; some of which will generate high-temperature steam in the steam generation system to drive the steam turbine generator set to generate electricity, and some of which will be preserved by the heat storage system in case of insufficient light situation (Qin 2018). These four types have their own advantages and disadvantages, and the technical characteristic comparison is shown in Table 2.

\section{Policy review}

CSP policies mainly include feed-in tariff, renewable energy quota systems, net metering tariff, fiscal and tax support 
Table 1 Some large-scale CSP projects in China

\begin{tabular}{|c|c|c|c|}
\hline Project & Technical route & Heat storage time & Operation time/operation status \\
\hline Supcon Delingha 10 MW CSP Demonstration Project & Molten Salt ST & 2 & 2016 year \\
\hline $\begin{array}{l}\text { Beijing Shouhang Dunhuang } 10 \text { MW Molten Salt } \\
\text { ST CSP Project }\end{array}$ & Molten Salt ST & 15 & 2016 year \\
\hline Huaqiang Zhaoyang Zhangjiakou CSP Project & Fresnel-like & 14 & 2018 year \\
\hline CGN Delingha 50MW PT CSP Project & PT (heat transfer oil) & 9 & Grid-connected on June 30, 2018 \\
\hline Shouhang Dunhuang 100MW Molten Salt ST CSP Project & Molten Salt ST & 11 & Grid-connected on December 28, 2018 \\
\hline Supcon Delingha 50MW Molten Salt ST CSP Project & Molten Salt ST & 6 & Grid-connected on December 30, 2018 \\
\hline $\begin{array}{l}\text { Gonghe 50MW Molten Salt ST CSP Project } \\
\text { (Power Construction Corporation of China) }\end{array}$ & Molten Salt ST & 6 & Grid-connected on September 19, 2019 \\
\hline Haixi Golmud 50MW Molten Salt ST CSP project & Molten Salt ST & 12 & Grid-connected in 2019 \\
\hline Hami 50MW Molten Salt ST CSP Project & Molten Salt ST & 13 & Grid-connected on December 29, 2019 \\
\hline Dacheng Dunhuang 50MW Molten Salt LFR CSP Project & Molten Salt Fresnel & 15 & Grid-connected on December 31, 2019 \\
\hline $\begin{array}{l}\text { Longteng 100MW PT CSP Project (China National } \\
\text { Nuclear Corporation) }\end{array}$ & PT (heat transfer oil) & 10 & Grid-connected on January 8, 2020 \\
\hline Yumen Xinneng 50 MW ST CSP Project & Secondary Reflection Molten Salt ST & 9 & Under construction \\
\hline $\begin{array}{l}\text { Beijing Guohua Power Yumen } 100 \text { MW Molten Salt } \\
\text { ST CSP Project }\end{array}$ & Molten Salt ST & 10 & Under construction \\
\hline Yumen Dongzhen PT CSP Project & PT (heat transfer oil) & 7 & Planned construction \\
\hline Zhongyang Chabei 64MW PT CSP Project & Molten Salt PT & 16 & Planned construction \\
\hline Sanxia Jjinta Molten Salt ST CSP Project & Molten Salt ST & 8 & Planned construction \\
\hline
\end{tabular}

Note: the sources are from Tong et al. (2019), Cai (2016), Wang (2018a), and Polaris 2020a

policies, and green power price, among which feed-in tariff and quota systems are the most widely used. In the feed-in tariff mechanism (FIT), the government mandates that electric power companies purchase renewable energy electricity generation within the coverage of the power grid at a certain price within a certain period of time ( $\mathrm{Su}$ 2017). Spain is the first country to adopt the FIT subsidy mechanism to promote the development of the CSP industry. Power Purchase Agreement (PPA) defines the price and rules at which power companies (usually public utilities) purchase renewable energy electricity generation ( $\mathrm{Su}$ 2017). The USA has the second largest installed capacity of CSP plants in the world, most of which have signed long-term PPA with power grid companies.

The "Twelfth Five-Year Plan" is the initial development period of CSP industry in China. During this period, CSP industry in China has achieved breakthrough development and forming documents such as the CSP station site selection, technology, guidelines, and industry standards. At the end of 2010, the installed capacity of CSP in China was still zero. The "13th Five-Year Plan" is a period of rapid development of CSP industry in China. During the period, China has strongly developed the CSP industry and introduced a series of policies and measures, and for instance, CSP should be included in the national CSP demonstration projects and should be managed and organized by NEA, and only projects that included in the list of demonstration projects are eligible for the electricity price subsidies. By the end of 2015, the installed capacity of CSP in China was 13.9MW. Compared with the total installed capacity (4940MW) of CSP plants that have been connected to the grid in the world, the installed capacity in China accounts for a small proportion, but it is a huge improvement
(Wang 2020). The rapid development of CSP industry has been inseparable from the policies issued by the government, as shown in Table 3.

\section{Methodology}

\section{LCOE mode}

The net present value method (NPV) is a commonly used method in project economic evaluation. But analyzing the economics of CSP, this method cannot be employed to analyze from a dynamic perspective, and there are certain limitations. The $L C O E$ model is a tool for comparing the unit costs of different technologies. It is used to evaluate or calculate the cost of different energy generation technologies (Pan et al. 2019). Unfortunately, the method used for calculating the $\angle C O E$ in the literature is far from uniform (Reichelstein and Yorston 2013; Levitt et al. 2011). Interested readers may refer to Larsson et al. (2014) for a perfect review on the methodological issues of $\angle C O E$ analysis. In this paper, based on the analysis framework proposed by E3 (2012), which, to the best scope of our knowledge, firstly conducted $L C O E$ analysis for various coal and gas generation technologies in China, we modify and improve the $L C O E$ model. In this way, our quantitative results for CSP can be directly compared with those of fossil power.

$L C O E$ refers to the ratio of the sum of the present value of various costs when the net present value is zero to the sum of the present value of energy production during the entire life cycle of a power generation project, that is, the unit power 
Table 2 The technical characteristics for CSP

\begin{tabular}{lllll}
\hline & PT & ST & SD & LFR \\
\hline Capacity (MW) & $10-200$ & $10-200$ & $0.01-0.4$ & $10-200$ \\
Concentration mode & Line & Point & Point & Line \\
Concentration ratio & $15-45$ & $\geq 1000$ & $\geq 1300$ & $10-40$ \\
Maturity & Commercialization & Commercial pilot & Demonstration & Pilot \\
Spotlight mode & Track & Fixed & Track & Fixed \\
Land use $\left(\mathrm{m}^{2} \mathrm{MWh}^{-1} \mathrm{y}^{-1}\right)$ & $6-8$ & $8-12$ & $8-12$ & $4-6$ \\
Efficiency $(\%)$ & $13-18$ & $16-17$ & $20-30$ & $8-11$ \\
Installation cost & Low & High & High & Low \\
Operating temperature & Low & High & High & Low \\
\hline
\end{tabular}

Note: the sources are from Amita Ummadisingu (2011), Suzan (2021), Du et al. (2016), Wang et al. (2016), and Yuan (2015)

generation cost. Under this unit power generation cost, the project can just reach the lowest expected rate of return, and the project does not have excess economic profit (Chen et al. 2015). In this paper, we use the whole life cycle analysis method to convert the expected future expenses into the present value through the discount rate $r$. At the end of the project life cycle $N$, the sum of the discounted value of income and the sum of the discounted value of costs are equal (see formula (1)).

$\sum_{n=0}^{N} \frac{\text { Revenues }_{n}}{(1+r)^{n}}=\sum_{n=0}^{N} \frac{\text { Cost }_{n}}{(1+r)^{n}}$

When the project cost is equal to the income, i.e., the net present value is 0 , the formula (2) is obtained.

$N P V=\sum_{n=0}^{N} P V=0$

Therefore, $L C O E$ is the cost of electricity per kilowatt hour when $N P V$ is 0 , that is, the project cost equals to the income. Revenues can be expressed as the product of $L C O E$ and annual generation, as shown in formula (3).

$\sum_{n=0}^{N} \frac{\left(L C O E_{n}\right) \times\left(E_{n}\right)}{(1+r)^{n}}=\sum_{n=0}^{N} \frac{\text { Cost }_{n}}{(1+r)^{n}}$

Assuming a constant annual value for the $L C O E$, formula (4) can be obtained.

$L C O E=\left(\sum_{n=0}^{N} \frac{\text { Cost }_{n}}{(1+r)^{n}}\right) /\left(\sum_{n=0}^{N} \frac{E_{n}}{(1+r)^{n}}\right)$

Formula (4) is the result of formula (3). From formula (4), we can see that $L C O E$ is equal to the sum of the discounted cost of the project's entire life cycle divided by the sum of the discounted annual energy output. There is another understanding of $L C O E$, that is, $L C O E$ is the price per unit of energy output. At this price, the above Eq. (2) can be realized and the project can be implemented. That is, the investor gets 0 profit after the end of the lifespan. It should be noted that the total calculation starts from $n=0$, including the initial investment cost of the project in the first year. This part does not need to be discounted, or the initial cost can be annualized throughout the life of the project. Formula (4) can be further evolved into formula (5).

$L C O E=\left(\sum_{n=1}^{N} \frac{\left(\text { CAPEX }_{n}+\text { OPEX }_{n}+T A X_{n}\right)}{(1+r)^{n}}\right) /\left(\sum_{n=1}^{N} \frac{\left(P \times\left(1-o_{u}\right)\right)_{n}}{(1+r)^{n}}\right)$

$C A P E X_{n}$ is the annual value of initial investment cost, including self-owned capital, loan, and depreciation, $O P E X_{n}$ is the annual value of operation and maintenance cost, including insurance expense, repair expense, and labor cost, $T A X_{n}$ is the annual tax amount of power plant, including business tax, value-added tax, and land tax, $P$ is the power electricity, $O_{\mathrm{u}}$ is own usage rate, $N$ is the service life of the plant, and $r$ is discount rate (Xu et al. 2020; Lin and Zhang 2017; Jiang et al. 2013; Yuan et al. 2016; Yang et al. 2019).

\section{Variables and factors}

The $L C O E$ value is the unit power generation cost during the life of CSP project. There are many influencing factors, including the capital expenditure (CAPEX), operation and maintenance costs $(O P E X)$, financial costs, tax costs, and capacity parameters.

Capital expenditure (CAPEX): the capital expenditure of CSP project mainly includes equipment purchase and installation engineering fees, construction engineering fees, other expenses (mainly land use fees and project construction management fees), and interest during the project construction period. The equipment mainly includes conventional island equipment, solar island equipment, heat storage system equipment, and auxiliary power generation system equipment. The solar island and heat storage system have the greatest impact on the investment cost of CSP projects. As for the PT project, 
Table 3 Policy review of CSP in China

\begin{tabular}{ll}
\hline Name & Issuer \\
\hline $\begin{array}{l}\text { "Decision on Accelerating the Cultivation and } \\
\text { Development of Strategic Emerging }\end{array}$ & State Council (SC 2010) \\
$\begin{array}{l}\text { Industries" } \\
\text { "Industrial Structure Adjustment Guidance } \\
\text { Catalog (2011 Edition)" }\end{array}$ & $\begin{array}{c}\text { National Development and Reform } \\
\text { "The Twelfth Five-Year Plan for Solar Power }\end{array}$ \\
NEA (NEA 2012)
\end{tabular}

Development"

"Notice on Organizing the Construction of CSP Demonstration Projects"

"Energy Technology Revolution and Innovation Action Plan (2016-2030)"

"The Thirteenth Five-Year Plan for Solar Energy Development"

"Notice on Benchmarking Feed-in Tariff Policy for CSP"

"Notice on the Construction of CSP Demonstration Projects"

"Notice on the Implementation of Renewable Energy Electricity Quota System (Draft for Solicitation of Comments)"

"Notice on Promoting the Construction of CSP Demonstration Projects"

"Industrial Structure Adjustment Guidance Catalog (2019 Edition)"
NEA (NEA 2015)

NEA (NEA 2016a)

NEA (NEA 2016b)

NDRC (NDRC 2016)

NEA (NEA 2016c)

NEA (NEA 2018a)

NEA (NEA 2018b)

NDRC (NDRC 2019)

NDRC (NDRC 2020)
Objectives

Year

The document clearly proposes to "open up a diversified solar $P V$ and CSP market."

In the fifth item of new energy, the CSP system is placed in a prominent position.

The plan clearly puts forward the installed capacity target and industrial development target for the end of 2015 in China. Among them, the installed capacity target of CSP is $1000 \mathrm{MW}$ on the premise that the economy is basically equivalent.

It is planned to construct the CSP demonstration plants with a scale of about $1 \mathrm{GW}$.

One of the development goals of high-efficiency solar energy utilization technology innovation in 2020 is to master the overall design and key component manufacturing technology of 50MW tower CSP and make a breakthrough of the integrated design and control technology of CSP.

By the end of 2020, the total installed capacity of CSP will reach $5 \mathrm{GW}$.

The benchmark feed-in tariff for CSP is 1.15 $\mathrm{RMB} / \mathrm{kWh}$ (including tax), and it is clear that the abovementioned electricity price is only applicable to the demonstration projects organized and implemented by NEA in 2016. At the same time, relevant departments of local governments are encouraged to adopt measures such as tax reduction and exemption, financial subsidies, green credit, and land concessions for CSP.

The first batch of domestic CSP demonstration projects was selected, with a total installed capacity of 1349MW, distributed in Qinghai, Gansu, Hebei, Inner Mongolia, Xinjiang, and other provinces, cities, and autonomous regions.

The renewable energy power quota formulated this time consists of two levels of renewable energy power quota indicators, namely "total quota" and "non hydropower quota." The "non hydropower quota" only includes the consumption of renewable energy power without hydropower, such as offshore wind power, onshore wind power, biomass power, solar $P V$, CSP, municipal solid waste power generation, geothermal power generation, and marine energy power generation.

The grid-connected period of the first batch of solar thermal demonstration projects has been extended: according to the actual situation of the demonstration projects, the construction period of the demonstration projects can be relaxed to December 31, 2020, at the same time, the electricity price retrogression mechanism for overdue commissioning will be established, and the specific price level will be specified by the NDRC in a separate document.

In the policy, CSP collection system, solar high temperature utilization technology development and equipment manufacturing, and other industries are included in the new energy incentive category.

$P V$, CSP, geothermal power, tidal power, wave power, garbage power, biogas power, $2.5 \mathrm{MW}$
2010 
Table 3 (continued)

\begin{tabular}{|c|c|c|c|}
\hline Name & Issuer & Objectives & Year \\
\hline $\begin{array}{l}\text { "Catalogue of Industries Encouraging Foreign } \\
\text { Investment (Draft for Solicitation of } \\
\text { Comments)" }\end{array}$ & & $\begin{array}{l}\text { and above wind power generation equipment, } \\
\text { and Stirling generator set manufacturing are } \\
\text { included in the new energy power generation } \\
\text { equipment or key equipment manufacturing. }\end{array}$ & \\
\hline $\begin{array}{l}\text { "Several Opinions on Promoting the Healthy } \\
\text { Development of Non-hydro Renewable } \\
\text { Energy Power Generation" }\end{array}$ & $\begin{array}{l}\text { NEA, NDRC, Ministry of Finance } \\
\text { (MOF) (NEA, NDRC, } \\
\text { and MOF 2020) }\end{array}$ & $\begin{array}{l}\text { It is clearly pointed out that the newly added } \\
\text { offshore wind power and CSP projects will no } \\
\text { longer be included in the scope of the central } \\
\text { financial subsidy, and the offshore wind power } \\
\text { and CSP projects that have been approved (put } \\
\text { on record) in accordance with relevant } \\
\text { regulations and have all units connected to the } \\
\text { grid by December } 31,2021 \text {, will be included in } \\
\text { the scope of central financial subsidies } \\
\text { according to the corresponding price policies. }\end{array}$ & 2020 \\
\hline
\end{tabular}

the cost of the solar island accounts for about $40 \%$ of the initial total investment, and the cost of the power generation system and the heat storage system both account for about $20 \%$ of the total investment ( $\mathrm{Su} 2017)$.

Operation and maintenance costs (OPEX): the operation and maintenance costs of CSP projects mainly include insurance, transportation, maintenance, wages, and welfare. Insurances and repair charges are given in the form of rates, which are 0.25 and $2 \%$ of the plant's fixed assets per year respectively (Zweibel 2010). According to the actual survey data, it is estimated that the 50MW CSP project needs 40 employees, and the annual employee salary is 80,000 RMB. The welfare labor insurance coefficient is set as $60 \%$ of the total salary, and the employee wage growth rate is $6 \%$.

Financial costs: the financial costs involved in calculating the $L C O E$ of the project mainly include the capital ratio, annual interest rate, loan period, after-tax internal recovery rate, discount rate, unit life, residual value rate, and depreciation rate. The construction cost of CSP projects is relatively high, and most of the investment comes from bank loans. According to the "Notice of the State Council on Strengthening the Capital Management of Fixed Asset Investment Projects," this paper sets the capital proportion to $20 \%$, and the other funds are financed by bank loans (SC 2019). Net residual value of fixed assets refers to the value of residual value minus the liquidation fee of fixed assets after the fixed assets reach the service life. The residual value rate in this paper is set as 5\% (STA 2019d). Since October 2015, the People's Bank of China has adjusted the long-term loan interest rate to $4.9 \%$ (MPD 2015). The loan period is 20 years, the design lifetime of the unit is 25 years, and the depreciation period is 20 years (NEA 2015). According to the standard of the power industry, the internal rate of return (IRR) of CSP projects is set at $8 \%$.

Tax cost: the tax cost of CSP projects mainly includes income tax, value-added tax (VAT), urban maintenance and construction tax, and education surcharge. The tax basis for tax purposes is different and needs to be determined according to the different situations. Under the implementation of the policy of "Replacing Business Tax with Value-added Tax," the operating tax of CSP projects will not be calculated. "The Announcement on the Continuation of the Enterprise Income Tax Policy for the Great Development of the West China" proposes that from January 1, 2021, to December 31, 2030, the enterprise income tax will be levied at a tax rate of $15 \%$ on enterprises in encouraged industries located in the western region (STA 2019a). According to "Regulations on the Implementation of the Enterprise Income Tax Law of the People's Republic of China," from the tax year of the first production and operation income of the project, the enterprise income tax is exempted from the first to the third year and reduced by half from the fourth to the sixth year (STA 2019b). Value-added tax has become one of the most important taxes in China. NEA issued "The Notice on Reducing the Tax Burdened on Enterprises in the Field of Renewable Energy," and implemented the VAT rate of $6.5 \%$ (STA 2019c; China 2017). Land use tax is levied on the land within the scope of cities, counties, organizational towns, and industrial and mining areas, and the actual occupied land area is the basis for tax calculation. The land use tax is levied at $2 \mathrm{RMB} / \mathrm{m}^{2}$ (Yuan et al. 2016). According to the relevant regulations on property tax, the tax rate is $1.2 \%$ and the property tax deduction ratio is $30 \%$ (TCPGPRC 2005a). In addition, urban maintenance and construction tax and education surcharge are based on value-added tax, which are $5 \%$ and $3 \%$, respectively (TCPGPRC 2020; TCPGPRC 2005b).

Capacity parameters and self-utilization rate: in order to effectively estimate the annual power generation of CSP during the operation period, we need to grasp important data such as the direct solar radiation intensity, installed capacity, expected annual utilization hours, and the self-use rate of power plants. These data need to be taken into consideration when 
designing the power station. The expected annual utilization hours of the project in this paper are set in line with the average annual utilization hours of various typical CSP projects in China (Qinghai 2020; China 2020; CSPPLAZA 2019c; CSPPLAZA 2017b; CSPPLAZA 2018). In addition, the self-use rate of power plants is set to $4 \%$ in this paper.

Discount rate: considering the time value of the funds, the discount rate of $8 \%$ is adopted to discount the funds in the whole life period of the project (Abbas et al. 2010).

Some parameter settings involved in the $L C O E$ calculation process of this paper are shown in Table 4.

\section{Parameterization and assumptions}

This paper takes 50MW PT CSP project, ST CSP project, secondary reflection ST CSP project, and LFR CSP project as examples. The $L C O E$ of different CSP projects is presented. The project characteristics are shown in Table 5. The PT and ST projects have been put into operation; however, both of them are the first large-scale projects in China, which require a long period of learning, and the operation of the power plant is not stable. In addition, because of the outbreak of COVID-19 in 2019, the power generation of CSP plants is also affected. These two reasons cause the actual power generation to be much smaller than the design value. Therefore, in order to eliminate the above reasons, this paper adopts the

Table 4 Specific parameters

\begin{tabular}{ll}
\hline Parameters & Value \\
\hline Residual value rate (\%) & $5 \%$ \\
Self-use rate of power plant (\%) & $4 \%$ \\
Capital ratio (\%) & $20 \%$ \\
Years of bank loan (year) & 20 \\
Annual interest rate (\%) & $4.9 \%$ \\
Internal recovery rate after tax (\%) & $8 \%$ \\
Unit life (year) & 25 \\
Income tax (\%) & $15 \%$ \\
Value-added tax (\%) & $6.5 \%$ \\
Land use tax (RMB/m $\left.{ }^{2}\right)$ & 2 \\
Discount rate (\%) & $8 \%$ \\
Premium rate (\%) & $0.25 \%$ \\
Major repair rate (\%) & $2 \%$ \\
Staff salaries (RMB/year) & 80,000 \\
Welfare and labor insurance coefficient (\%) & $60 \%$ \\
Annual growth rate of employees' wages $(\%)$ & $6 \%$ \\
Number of staff & 40 \\
Urban maintenance and construction tax (\%) & $5 \%$ \\
Education surcharges (\%) & $3 \%$ \\
Property tax (\%) & $1.2 \%$ \\
\hline
\end{tabular}

designed annual power generation, and other data such as the total investment of the power plant adopt the actual value. With the emerging technology, the secondary reflection ST project is still under construction, and there is no actual data, so the data in this article adopts the project design value. In addition, for the SD technology, because it currently only has a demonstration project, it is of no reference for economic evaluation.

\section{Results}

Based on $\angle C O E$ model, the $L C O E$ of different CSP projects is calculated (Figure 2). The $L C O E$ of PT project is $1.11 \mathrm{RMB} /$ $\mathrm{kWh}(0.17 \mathrm{US} \$ / \mathrm{kWh})$, the ST project is $0.93 \mathrm{RMB} / \mathrm{kWh}(0.14$ $\mathrm{US} \$ / \mathrm{kWh}$ ), the secondary reflection ST project is $0.97 \mathrm{RMB} /$ $\mathrm{kWh}(0.15 \mathrm{US} \$ / \mathrm{kWh})$, and the LFR project is $0.92 \mathrm{RMB} /$ $\mathrm{kWh}(0.14 \mathrm{US} \$ \mathrm{kWh})$.

In the "Parameterization and assumptions" section, it has been mentioned that the PT and ST projects have been connected to the grid, and the initial investment is based on the actual value; the secondary reflection ST and LFR projects are still under construction owing to the slow development, so the initial investment is based on the design value. CSP project has a long construction period and many uncertain factors such as technology, market, and economic environment, so the actual value of the initial investment of the project is usually greater than the design value, which will cause the $L C O E$ of the secondary reflection ST, and the LFR is lower than the actual. Since PT and ST systems are the dominant commercial technologies in China, these two technologies are the focus of this paper.

In this paper, the PT project has 9-h heat storage device, and the heat transfer fluid is heat transfer oil; the ST has 6-h heat storage device, and the heat transfer fluid is molten salt. Initial investment and annual power generation are the most critical factors affecting $L C O E$. The main reason for the difference of initial investment cost of different CSP projects is solar island and heat storage system, and the heat storage time is an important factor to determine the annual power generation. In Table 5, the initial investment of PT is $38000 \mathrm{RMB} /$ $\mathrm{KW}$ and $\mathrm{ST}$ is $22,600 \mathrm{RMB} / \mathrm{KW}$, which is caused by many reasons. First, the time for PT heat storage is long, which results in the investment of heat storage system higher than the ST. Second, the heat transfer fluid used in the PT and ST is different. The temperature difference of the PT system is generally lower than $100^{\circ} \mathrm{C}$ for the limitation of the maximum operating temperature of heat transfer oil, while the molten salt temperature difference of heat transfer fluid in the ST system is large, and the operating temperature is high, so the PT system needs more heat transfer oil and larger storage tank to maintain the same energy. Third, it is the cost deviation caused by the selected project itself. The 50 MW ST project 
is based on the original $10 \mathrm{MW} \mathrm{ST} \mathrm{project.} \mathrm{In} \mathrm{the} \mathrm{process} \mathrm{of}$ construction, project managers have accumulated rich experience and the ability to deal with emergencies, so the construction cost of the project is low. Moreover, the company is committed to building its own brand. The core equipment (heliostat, collector, etc.), products, and services are provided by the company itself, and the localization rate has reached more than $95 \%$. The three reasons mentioned above cause the significant differences in the initial investment cost of the power station, which results in the higher $L C O E$ of the PT than the ST.

Molten salt ST is a new technology developed in recent years. It is generally considered that its maturity is not as high as PT type is. However, ST has good light concentration effect, high solar energy conversion rate, and large space for improving power generation efficiency. Although ST is a later-comer, there are more demonstration projects employed ST. With the ability to operate at higher temperatures than PT, ST has the potential to surpass PT as the most competitive CSP option.

The secondary reflection ST is an emerging technology of ST. Compared with the traditional ST technology, it has high safety, short construction period, convenient operation and maintenance, etc. It is a CSP technology with great development potential. However, due to its immaturity, the $L C O E$ value is a little higher than ST. Due to high power generation efficiency and high annual utilization hours, LFR has the smallest $L C O E$ value.

Although there are differences among these types of CSP, the differences are not significant, and they are all lower than the current benchmark feed-in tariff of $1.15 \mathrm{RMB} / \mathrm{kWh}$. Judging from the commercialization development scale and data analysis results of existing CSP projects, ST technology may be the main technical direction of CSP in the future.

\section{Policy implications}

Although the LCOE of CSP is lower than the current benchmark feed-in tariff, it is still much higher than the coal price. The main reason is that the initial investment cost is too high.
In order to encourage the development of CSP industry, the government should consider the following aspects:

\section{(1) Preferential loans policies}

The scale of CSP project is large, and the initial investment cost is too high, but the company's capital chain is short, resulting in a large loan amount, and the loan interest rate has a greater impact on its cost. At present, the loan interest rate provided by Chinese commercial banks for CSP projects is $4.9 \%$, and financing costs account for a large proportion of the $L C O E$. Therefore, for CSP projects, national policy banks should provide preferential loans to reduce financing costs, thereby reducing the $L C O E$.

\section{(2) Tax incentives}

According to the current policy, although the land used by CSP projects is unused land such as desert and Gobi, in fact, the land cost of some projects still accounts for a large proportion of the $L C O E$. The government should give preferential land use policies and land tax reduction policies for CSP projects to reduce the $L C O E$ of CSP. With regard to enterprise income tax and value-added tax, although the government has given preferential policies, there are still some problems such as that the preferential policies cannot be issued in time. Therefore, establish a rounded fiscal and tax support policy mechanism and encourage relevant local government departments to take measures such as tax reductions and exemptions, financial subsidies, green credits, and land concessions for CSP projects.

\section{(3) R\&D fund support}

At present, there are still many obstacles in the development of CSP, such as immature technological development, small developmental scale, and a shortage of core equipment which have to be imported from abroad. Therefore, government should encourage enterprises to make technological innovation and breakthroughs in key technologies, improve the

Table 5 Project characteristics

\begin{tabular}{lllll}
\hline & PT & ST & $\begin{array}{l}\text { Secondary } \\
\text { reflection ST }\end{array}$ & LFR \\
\hline Total unit investment (billion RMB) & 1.9 & 1.13 & 1.79 & 1.688 \\
Installed capacity (MW) & 50 & 50 & 50 & 50 \\
Heat storage time (h) & 9 & 6 & 9 & 15 \\
Heat transfer fluid & Heat transfer oil & Molten salt & Molten salt & Molten salt \\
Initial investment cost (RMB/KW) & 38,000 & 22,600 & 35,800 & 33,760 \\
Expected generation (MWh/year) & 197,500 & 146,000 & 216,000 & 214,000 \\
Expected annual hours (h/year) & 3950 & 2920 & 4320 & 4283 \\
Unit area (m $/ \mathrm{MW})$ & 50,000 & 49,400 & 73,800 & 63,720 \\
\hline
\end{tabular}


Fig. 2 The $L C O E$ of different CSP projects

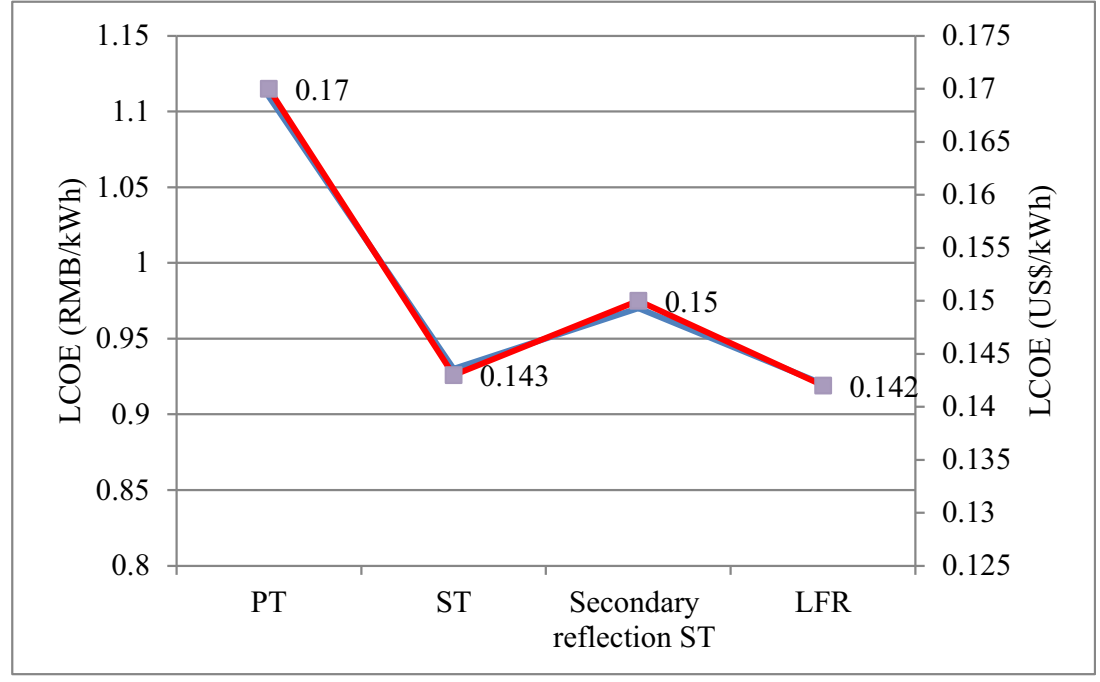

efficiency of photothermal conversion and annual utilization hours, reduce the CSP cost by using economies of scale, and commit to the research and development of key equipment and materials to improve the level of equipment localization.

\section{Conclusion}

Renewable energy is about to be ready for upcoming grid parity. Although China's CSP industry started very late, the government had adopted a series of policies to encourage foreign investment, actively construct CSP demonstration projects, and carry out tax incentives, etc., so that CSP develops at a high speed and gradually forms a scale. At present, a variety of large-scale CSP demonstration projects have been connected to the grid and successfully generated electricity.

After the construction of the first batch of CSP projects, China has cultivated a relatively mature industry chain. CSP technology also becomes more mature, secondary reflection ST, supercritical $\mathrm{CO}_{2} \mathrm{CSP}$ technology has been in the international leading level, and the independent research and development capacity of key technologies have been greatly improved. However, there are still many core technologies that have not been mastered, and there is still a gap with other countries of the world. Therefore, the government should give R\&D fund support to improve the technical standards of CSP industry and standardize the technical requirements, so that the CSP can get a breakthrough in technology.

In this paper, $L C O E$ is carried out to analyze and evaluate different types of CSP technologies in China from an economic perspective. The results show that the LCOE of several CSP projects is lower than the current benchmark feed-in tariff, among which ST projects currently have the most cost advantage and great potential. Furthermore, subsidies for clean energy technologies are also an effective method to reduce the cost of new technologies and accelerate the substitution of energy technologies. However, according to the current policy, the new CSP projects after 2021 will not be able to obtain the national subsidy and will be supported by local governments according to the actual situation, which may hinder the development of the CSP industry. Therefore, in order to promote the development of CSP industry, the government should consider carefully when formulating policies and should not cancel the financial subsidies too early. This paper proposes policy implications for preferential loans, tax incentives, and R\&D fund support to provide practical guidance for CSP in China in the upcoming era of low-cost CSP.

Acknowledgements The authors would also like to acknowledge great thanks to anonymous reviewers for their valuable comments which largely improve the academic quality of this paper. The usual caveats apply.

Author contribution All authors contributed to the study conception and design. Data collection and analysis were performed by J. P and J.Y. The first draft of the manuscript was written by Y.X and G. Z, and all authors commented on previous versions of the manuscript. All authors read and approved the final manuscript.

Funding This study was funded by the Fundamental Research Funds for the Central Universities (2018ZD14), National Natural Science Foundation of China (71774105), Program for the Innovative Talents of Higher Education Institutions of Shanxi (PTIT) and Program for the Philosophy and Social Sciences Research of Higher Learning Institutions of Shanxi (2020W061), and Philosophy and Social Science Planning Program of Shanxi (2020YJ110).

Data availability All data generated or analyzed during this study are included in this published article.

\section{Declarations}

Ethics approval Not applicable.

Consent to participate Not applicable. 
Consent for publication Not applicable.

Competing interests The authors declare no competing interests.

\section{References}

Abbas M, Boumeddane B, Said N et al (2010) Dish Stirling technology: a $100 \mathrm{MW}$ solar power plant using hydrogen for Algeria. Int J Hydrog Energy 36(7)

Amita Ummadisingu MS (2011) Concentrating solar power - technology, potential and policy in India. Renew Sust Energ Rev 15:51695175

Balghouthi M, Trabelsi SE, Amara MB, Ali ABH, Guizani A (2016) Potential of concentrating solar power (CSP) technology in Tunisia and the possibility of interconnection with Europe. Renew Sust Energ Rev 56:1227-1248

Bosetti V, Catenacci M, Fiorese G, Verdolini E (2012) The future prospect of PV and CSP solar technologies: an expert elicitation survey. Energy Policy 49:308-317

Burkhardt JJ, Heath G, Cohen E (2012) Life cycle greenhouse gas emissions of trough and tower concentrating solar power electricity generation. J Ind Ecol 16(S1):S93-S109

Cai ZY (2016) China's first large-scale molten salt energy storage thermal power station successfully put into operation. Hangzhou (weekly) 426(19):58 (in Chinese)

Chen X, Fan HT (2012) Development status of solar thermal power generation technology. Energy Environ 110(1):90-92 (in Chinese)

Chen RR, Sun YL, Chen SM, Shen H (2015) LCOE analysis of gridconnected photovoltaic power generation projects. Renew Energy 33(5):731-735 (in Chinese)

China Power Grid (2017) Reducing the VAT tax burden of hydropower enterprises: notice of the National Energy Administration on reducing the tax burden of enterprises in the field of renewable energy. Available at: http://news.bjx.com.cn/html/20170912/849523.shtml . Accessed 20 October 2020

China energy storage network (2020) Lanzhou Dacheng Dunhuang 50MW Molten Salt Linear Fresnel Photothermal Power Station was put into operation. Available at: http://www.escn.com.cn/ news/show-1062034.html. Accessed 20 October 2020

Cirocco LR, Belusko M, Bruno F, Boland J, Pudney P (2016) Maximising revenue via optimal control of a concentrating solar thermal power plant with limited storage capacity. Iet Renew Power Gener 10(5):729-734

CSPFocus Photothermal Power Generation Information(2019). The grid connection of Hami 50MW tower photothermal power generation project was successful at one time. Available at: http://guangfu.bjx. com.cn/news/20191230/1032410.shtml. Accessed 20 October 2020

CSPPLAZA photothermal power generation network (2017a) Successful trial operation of Yanqing 1MW trough solar thermal power generation project, a national 863 project. Available at: http://www. cspplaza.com/article-9647-1.html. Accessed 20 October 2020

CSPPLAZA photothermal power generation network (2017b) Yumen Xinneng secondary reflection 50MW molten salt tower photothermal demonstration project is under construction. Available at: http://www.cspplaza.com/article-9959-1.html . Accessed 20 October 2020

CSPPLAZA photothermal power generation network (2018) Super project-China's first large-scale photothermal demonstration power station, CGNPC Delingha 50MW trough power station, was officially put into operation. Available at: http://www.cspplaza.com/ article-13377-1.html. Accessed 20 October 2020

CSPPLAZA photothermal power generation network (2019a) The $50 \mathrm{MW}$ fused salt tower photothermal power generation project of
Qinghai Gonghe was successfully connected to the grid once. Available at: http://www.cspplaza.com/article-16136-1.html. Accessed 20 October 2020

CSPPLAZA photothermal power generation network (2019b) Luneng Haixi Golmud 50MW tower photothermal power generation project was successfully connected to the grid once. Available at: http:// www.cspplaza.com/article-16150-1.html. Accessed 20 October 2020

CSPPLAZA photothermal power generation network (2019c) Operation of Qinghai Zhongkong Delingha 50MW Molten Salt Tower Photothermal Power Station and Sharing of Operation and Maintenance Experience. Available at: http://www.cspplaza.com/ article-15658-1.html. Accessed 20 October 2020

CSPPLAZA photothermal power generation network (2020a) In 2019, the installed capacity of global solar thermal power generation increased to $6451 \mathrm{MW}$, and China contributed $52.41 \%$ of new capacity. Available at: http://www.cspplaza.com/article-17037-1.html. Accessed 20 October 2020

CSPPLAZA photothermal power generation network (2020b) Regarding the change of the photothermal demonstration project, the National Energy Administration, the owner unit, replied. Available at: http:// www.cspplaza.com/article-18814-1.html . Accessed 20 October 2020

CSPPLAZA photothermal power generation network (2020c) Luneng Haixi state multi-energy complementary integration optimization national demonstration project has achieved good results again, how to realize multi-energy optimization combination? Available at: http://www.cspplaza.com/article-18254-1.html . Accessed 20 October 2020

Ding S, Zhang M, Song Y (2019) Exploring China's carbon emissions peak for different carbon tax scenarios. Energy Policy 129:12451252

Dominguez R, Baringo L, Conejo A (2012) Optimal offering strategy for a concentrating solar power plant. Appl Energy 98:316-325

Du ES, Zhang N, Kang CQ, Miao M (2016) Review and prospect of research on grid-connected operation and optimization planning of solar photovoltaic power generation. Proceedings of the CSEE 36 (21):5765-5775+6019 (in Chinese)

Du ES, Zhang N, Hodge B, Kang C, Kroposki B et al (2018) Economic justification of concentrating solar power in high renewable energy penetrated power systems. Appl Energy 225:649-661

Energy+ Environmental Economics (E3) (2012) Generation cost model for China. E3: San Francisco, CA, USA. Available at: https://ethree. $\mathrm{com} /$ public projects/generation cost model for china.php

Flueckiger SM, Iverson BD, Garimella SV , Pacheco JE (2014) Systemlevel simulation of a solar power tower plant with thermocline thermal energy storage. Appl Energy 113:86-96

Fujii H, Iwata K, Chapman A, Kagawa S, Managi S (2018) An analysis of urban environmental Kuznets curve of $\mathrm{CO} 2$ emissions: empirical analysis of 276 global metropolitan areas. Appl Energy 228:15611568

Gansu daily (2020) Lanzhou Dacheng Dunhuang 50MW Molten Salt Linear Fresnel Photothermal Power Station was put into operation. Available at: http://www.gansu.gov.cn/art/2020/7/8/art_36_ 456919.html. Accessed 20 October 2020

Janjai S, Laksanaboonsong J, Seesaard T (2011) Potential application of concentrating solar power systems for the generation of electricity in Thailand. Appl Energy 88(12):4960-4967

Jiang H, Xu FY, Bai XK et al (2013) Flow algorithm for $\beta$ ratio throat-tap nozzle which can control the system configuration easily. Thermal Power Generation 42:123-126 (in Chinese)

Larsson S, Fantazzini D, Davidsson S, Kullander S, Mikael H (2014) Reviewing electricity production cost assessments. Renew Sust Energ Rev 30:170-183

Levitt AC, Kempton W, Smith AP, Musial W, Firestone J (2011) Pricing offshore wind power. Energy Policy 39(10):6408-6421 
Li G (2012) Research on modeling and control strategy of 1 MW Tower Solar Power Generation System. North China Electric Power University, Dissertation (in Chinese)

Li X, Zhao XH, Li JY, Li W, Xu N et al (2015) Life cycle cost electricity price analysis of tower solar thermal power generation. Power System Automation 39(7):84-88 (in Chinese)

Lin L, Zhang B (2017) Analysis and diagnosis of high coal consumption of No.1 and No.2 units of Hebei Jiantou Xuanhua Thermal Power Co., Ltd.; Xi'an Thermal Power Research Institute Co. Xi'an, China, pp 97-123

Lu ZN, Luo YS (2020) Analysis on the effectiveness of carbon trading policy in China-application and test of double difference method. J Arid Land Resour Environ 34(4):1-7 (in Chinese)

Monetary Policy Department(2015) RMB current interest rate table (October 24, 2015). Available at: http://www.pbc.gov.cn/ zhengcehuobisi/125207/125213/125440/125838/125885/125896/ 2968988/index.html. Accessed 2 December 2020

NDRC (2011) Industrial structure adjustment guidance catalog (2011 Edition). Available at: https://www.ndrc.gov.cn/fggz/cyfz/zcyfz/ 201104/t20110426_1149263.html. Accessed 2 December 2020

NDRC (2016) Notice on benchmarking feed-in tariff policy for CSP . Available at: https://www.ndrc.gov.cn/xxgk/zcfb/tz/201609/ t20160902 963176.html.

NDRC (2019) Industrial structure adjustment guidance catalog (2019 Edition). Available at: http://www.gov.cn/xinwen/2019-11/06/ content_5449193.htm. Accessed 2 April 2021

NDRC (2020) Catalogue of industries encouraging foreign investment (draft for solicitation of comments). Available at: https://www.ndrc. gov.cn/yjzxDownload/20200731glwstz1.pdf. Accessed 2 December 2020

NEA (2012) The twelfth five-year plan for solar power development . Available at: http://www.gov.cn/zwgk/2012-09/13/content 2223540.htm. Accessed 2 December 2020

NEA (2015) Notice on organizing the construction of solar thermal power demonstration project. Available at: http://zfxxgk.nea.gov.cn/ auto87/201509/t20150930 1968.htm. Accessed 2 December 2020

NEA (2016a) Energy technology revolution and innovation action plan (2016-2030). Available at: http://www.nea.gov.cn/2016-06/01/c 135404377.htm. Accessed 2 December 2020

NEA (2016b) Thirteenth five-year plan for solar energy development . Available at: http://zfxxgk.nea.gov.cn/auto87/201612/t20161216_ 2358.htm. Accessed 2 December 2020

NEA (2016c) Notice on the construction of CSP demonstration projects . Available at: http://zfxxgk.nea.gov.cn/auto87/201609/t20160914 2298.htm. Accessed 2 December 2020

NEA (2018a) Notice on the implementation of renewable energy electricity quota system (Draft for Solicitation of Comments). Available at: http://www.nea.gov.cn/2018-11/15/c_137607356.htm.

NEA (2018b) Notice on promoting the construction of solar thermal power demonstration projects. Available at: http://zfxxgk.nea.gov. cn/auto87/201805/t20180522_3180.htm. Accessed 2 April 2021

NEA (2020) Reply to recommendation No.7063 of the third session of the 13th National People's Congress . Available at: http://zfxxgk. nea.gov.cn/2020-09/09/c 139419515.htm. Accessed 2 December 2020

NEA, NDRC, MOF (2020) Several opinions on promoting the healthy development of non-hydro renewable energy power generation . Available at: http://jjs.mof.gov.cn/zhengcefagui/202001/ t20200122 3463379.htm. Accessed 2 December 2020

Ning YD, Chen KK, Zhang By, et al (2020) Energy conservation and emission reduction path selection in China: a simulation based on bilevel multi-objective optimization model. Energy Policy. 137.

Niu ZY, Li LJ (2020). Present situation and analysis of solar thermal power demonstration project . Energy and Energy Saving, Volume Missing (12), 76-77+156 (in Chinese)
Ou JM, Meng J, Shan YL, Zheng H, Mi Z, Guan D (2019) Initial declines in China's provincial energy consumption and their drivers. Joule 3 (5):1163-1168

Pan ZT, Hao J, Wang J (2017) Development status and prospect of solar power generation technology. Sci Technol Innov Herald 14(26): 100-103 (in Chinese)

Pan BB, Chen ZH, Jia NF, Li YH, Hao Y (2019). Research on cost accounting of photovoltaic power generation-analysis based on LCOE method . Price Theory and Practice 419(5):138-140+ 144 (in Chinese)

Parrado C, Marzo A, Fuentealba E, Fernández A (2016) 2050 LCOE improvement using new molten salts for thermal energy storage in CSP plants. Renew Sust Energ Rev 57:505-514

Petrollese M, Cocco D, Cau G, Cogliani E (2017) Comparison of three different approaches for the optimization of the CSP plant scheduling. Sol Energy 150:463-476

Polaris solar photovoltaic network (2020a). What is the status quo of the first 20 demonstration projects of solar thermal power generation. Available at: http://guangfu.bjx.com.cn/news/20200304/1050544. shtml. Accessed 2 April 2021

Polaris solar photovoltaic network (2020b). Detailed explanation of $10 \mathrm{MW}+50 \mathrm{MW}$ photovoltaic power station in Delingha, Qinghai Province. Available at: http://guangfu.bjx.com.cn/news/20200628/ 1084202.shtml. Accessed 2 December 2020

Qin C (2018) Application analysis of heat transfer oil and molten salt in photothermal power generation. Low Carbon World 186(12):34-35 (in Chinese)

Qinghai provincial government (2020) CGNPC Delingha 50 MW CSP project and Qinghai Zhongkong CSP project are included in the State Grid subsidy list. Available at: http://www.haixi.gov.cn/info/ 1690/197799.htm. Accessed 2 December 2020

Reichelstein S, Yorston M (2013) The prospects for cost competitive solar PV power. Energy Policy 57:117-127

SC (2010) Decision on accelerating the cultivation and development of strategic emerging industries. Available at: http://www.gov.cn/ zwgk/2010-10/18/content_1724848.htm. Accessed 2 December 2020

SC (2019) Notice on strengthening capital management of fixed assets investment projects. Available at: http://www.gov.cn/zhengce/ content/2019-11/27/content_5456170.htm. Accessed 2 December 2020

Shah R, Yan RF, Saha T K (2014) Performance assessment of solar thermal powe plants:a case study in Queensland//Proceedings of IEEE PES General Meeting. National Harbor, MD, US:IEEE

Sharma C, Sharma AK, Mullick SC, Kandpal TC (2016) A study of the effect of design parameters on the performance of linear solar concentrator based thermal power plants in India. Renew Energy 87: 666-675

Song Y, Zhang M (2019) Study on the gravity movement and decoupling state of global energy-related $\mathrm{CO}_{2}$ emissions. J Environ Manag 245: 302-310

Song Y, Zhang M, Sun RF (2019). Using a new aggregated indicator to evaluate China's energy security. Energy Policy. 132.

Song Y, Sun JJ, Zhang M, Su B (2020) Using the Tapio-z decoupling model to evaluate the decoupling status of China's $\mathrm{CO} 2$ emissions at provincial level and its dynamic trend. Struct Chang Econ Dyn 52 (9):120-129

State Taxation Administration (2019a) Enterprise Income Tax Law of the People's Republic of China. Available at: http://www.chinatax.gov. cn/chinatax/n810341/n810825/c101434/c28479830/content.html. Accessed 2 December 2020

State Taxation Administration (2019b) Regulations on the implementation of the Enterprise Income Tax Law of the People's Republic of China. Available at: http://www.chinatax.gov.cn/chinatax/n810341/ n810825/c101434/c28479831/content.html. Accessed 2 December 2020 
State Taxation Administration (2019c) Announcement on deepening the relevant policies of value-added tax reform. Available at: http:// www.chinatax.gov.cn/n810341/n810755/c4160283/content.html. Accessed 2 December 2020

State Taxation Administration (2019d). Regulations for the implementation of the enterprise income tax law of the People's Republic of China. Available at: http://www.chinatax.gov.cn/chinatax/n810341/ n810825/c101434/c28479831/content.html. Accessed 20 June 2021.

State-owned Assets Supervision and Administration Commission of the State Council (SASAC) (2018) China's first large-scale commercial photothermal demonstration power station was officially put into operation. Available at: http://www.sasac.gov.cn/n2588025/ n2588124/c9676847/content.html. Accessed 2 December 2020

$\mathrm{Su} \mathrm{J}$ (2017) Economic analysis and development policy research of solar photothermal power generation industry. North China Electric Power University (Beijing), Dissertation (in Chinese)

Sun YL (2020) How much do we still need to achieve carbon neutrality. Wind Energy 128(10):42-44 (in Chinese)

Sun XQ, Bai Y (2017) Current situation of solar thermal power generation technology and analysis of problems existing in key equipment. China Sci Technol Inf 572(23):72-75 (in Chinese)

Suzan A (2021) Performance and cost evaluation of solar dish power plant: sensitivity analysis of levelized cost of electricity (LCOE) and net present value (NPV). Renew Energy 168:332-342

The Central People's Government of the People's Republic of China (2005a). Provisional regulations of the People's Republic of China on real estate tax. Available at: http://www.gov.cn/banshi/2005-08/ 19/content 24823.htm. .

The Central People's Government of the People's Republic of China (2005b). Decision of the state council on amending the interim provisions on the collection of educational surcharges. Available at: http://www.gov.cn/zwgk/2005-09/27/content_70440.htm. Accessed 20 June 2021.

The Central People's Government of the People's Republic of China (2020). Tax law of the people's Republic of China on urban maintenance and construction. Available at: http://www.gov.cn/xinwen/ 2020-08/11/content_5534188.htm. Accessed 20 June 2021.

Tong JL, Lu HK, Li RP et al (2019) Overview of domestic solar thermal power generation status and application prospects. Zhejiang electric power 38(12):25-30 (in Chinese)

Wang Z (2009) Prospectives for China's solar thermal power technology development. Energy 35(11)

Wang L (2018a) China's first large-scale solar thermal demonstration power station officially put into operation. Power equipment management 25(10):92 (in Chinese)
Wang M (2018b) Spatial effect of environmental regulation on carbon emissions. Meteorol Environ Res 9(01):57-61

Wang K (2020). The 14th five-year plan of photothermal power generation: the critical period of breaking the bureau . Energy, Volume Missing (Z1): 70-74 (in Chinese)

Wang GW, Xu SY, Han L, Sun HB (2014) Review on the main technologies and applications of solar thermal utilization. Materials Guide 28(S1):193-196 (in Chinese)

Wang D, Shi Y, Hu JT, Liu C, vilen (2016) Summary of solar thermal power generation technology and its applicability analysis in China. Power Grid Clean Energy 32(9):151-156 (in Chinese)

Xin Hua Net (2020) China Renewable Energy Development Report 2019. Available at: http:/www.xinhuanet.com/energy/2020-07/23/ c_1126275186.htm. Accessed 2 December 2020

Xu Y, Yang K, Yuan JH (2020) China's power transition under the global $1.5^{\circ} \mathrm{C}$ target: preliminary feasibility study and prospect. Environ. Sci. Pollut. Res. 27(13):15113-15129

Yang L, Jiang H, Jing XJ, Zeng LF (2019) Steady state detection method and application based on uncertainty theory. Thermal Power Generation 48:139-144 (in Chinese)

Yuan WD (2015) Present situation and prospect of solar thermal power generation at home and abroad. Electricity and Energy 36(4):487490 (in Chinese)

Yuan JH, Na CN, Xu Y, Zhao CH (2016) Feed-in tariff for onshore wind power in China. Emerg Mark Financ Trade 52(4-6):1427-1437

Zhang HY (2018) Economic research on centralized photovoltaic power generation in China. North China Electric Power University (Beijing), Dissertation (in Chinese)

Zhang C, Su B, Zhou KL, Yang SL (2019) Decomposition analysis of China's CO2 emissions (2000-2016) and scenario analysis of its carbon intensity targets in 2020 and 2030. Sci Total Environ 668: $432-442$

Zhang L,Wang QY, Zhang M (2021). Environmental regulation and CO2 emissions: based on strategic interaction of environmental governance. Ecological Complexity. 45.

Zhu Z, Zhang D, Mischke P, Zhang X (2015) Electricity generation costs of concentrated solar power technologies in China based on operational plants. Energy 89:65-74

Zweibel K (2010) Should solar photovoltaics be deployed sooner because of long operating life at low, predictable cost? Energy Policy, 2010, 38(11).

Publisher's note Springer Nature remains neutral with regard to jurisdictional claims in published maps and institutional affiliations. 